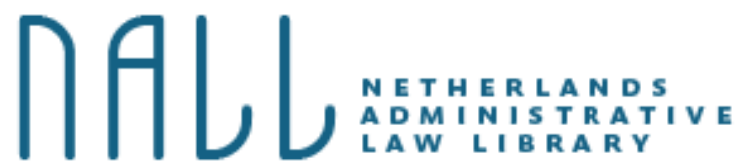

Citeerwijze van dit artikel:

prof. dr. Tom Barkhuysen, prof. dr. Willemien Ouden en dr. Ymre E. Schuurmans, 'The Law on Administrative Procedures in the Netherlands', NALL 2012, april-juni, DOI:

10.5553/NALL/.000005

DOI: 10.5553/NALL/.000005

\title{
The Law on Administrative Procedures in the Netherlands
}

prof. dr. Tom Barkhuysen, prof. dr. Willemien Ouden en dr. Ymre E. Schuurmans

\section{Introduction}

In the Netherlands law in general embodies two kinds of legal rules concerning administrative procedures. First, there are hundreds if not thousands of statutory provisions that grant administrative authorities the power to act for the purpose of performing a public service and that regulate such action in a detailed way. This includes specific rules in numerous branches of law, such as social security law, immigration law or environmental law. Further, since 1994 the Netherlands has had the General Administrative Law Act ('GALA') (Algemene wet bestuursrecht or Awb), which contains rules for orders made by administrative authorities and that creates the right of appeal to an administrative court. ${ }^{\mathbf{1}}$ This Act regulates the process of administrative decisionmaking in a general sense and provides a general framework for legal protection against the orders issued.

In this contribution, we will first describe the history of Dutch administrative law and the GALA, with a focus on administrative procedures. ${ }^{\mathbf{2}}$ With the sketch of that law system in mind, it will be easier to comment on the scope of the comparison. We chose not to include detailed source references, because more detailed information is available only in Dutch-language publications. For general information on Dutch administrative law, we would like to refer to some renowned handbooks. ${ }^{3}$

\section{Historical Development}

The development of the Dutch law on administrative procedures should be viewed in relation to the nature and extent of government action in the Netherlands. ${ }^{4}$ Until the second half of the nineteenth century, such government action comprised, apart from legislation, primarily the regulation and maintenance of public order. The major expansion of government action did not 
take place until the second half of the nineteenth century as a result of the democratisation of society and the adoption of general suffrage, first for men (in 1917) and soon afterwards, for women (1922). The subsequent socialization of society meant that the government adopted many measures in such fields as working conditions, public housing and public health. Due to the economic crisis of the 1930 and the emergency measures the government took to deal with this crisis, government regulation of economic matters became common. After the Second World War, the reconstruction of the Netherlands required government action in a variety of fields in society. The nation's rapidly growing prosperity soon prompted the government to create an extensive social security system, bringing the scale of government action and the underlying legislation in the Netherlands to a climax. Since the 1980s, the Dutch public debate has triggered continuing calls for slimming down the machinery of government, reducing the number of government responsibilities and deregulation. Even though these have invariably been official objectives of the successive governments since then, not much progress has been made in these areas. In practice, it turns out that reducing government responsibilities, civil servants and government rules is difficult to achieve.

Administrative law in the Netherlands has not had a long tradition of judicial review of administrative authorities. Traditionally, legal protection has been organized mainly within the administrative system. Administrative powers are created and regulated in separate statutes, which frequently create special legal procedures as well. This has given rise to a highly fragmented system of administrative procedures, somewhat like the English tribunal system. 5

In the period after the Second World War, which witnessed the sharpest increase in government action and the regulatory framework underlying it, the technique of 'delegated rulemaking power' (gelede normstelling) also reached its full potential in the Netherlands. This technique means that specific rules are not just laid down in statutes but that, quite frequently, rulemaking powers are delegated to subordinate legislators. Besides, such legislation often confers discretionary administrative powers on public authorities on a large scale. Due to the enormous size and diversity of administrative law and the phenomenon of delegated rulemaking powers, administrative law became a complex branch of law.

Accordingly, calls for systematization and simplification through codification were to be expected. ${ }^{\mathbf{6}}$ The first few Dutch administrative statutes designed to harmonize the law in a general sense addressed mainly the issue of legal protection. The Administrative Decisions (Review) Act of 1963 (Wet beroep administratieve beschikkingen) created the possibility of administrative appeal to the Crown (hence, the administration) against all decisions of the central government against which there was no other legal protection. In 1976, this Act was replaced by the Administrative Decisions (Appeals) Act (Wet administratieve rechtspraak overheidsbeschikkingen), which provided for appeals against nearly all administrative decisions that were not subject to another legal protection system to be brought to a new administrative court: the Judicial Division of the Council of State. The case law of this division helped to harmonize administrative law, but the urge for a general codification effort was 
still felt broadly. In 1983, it was laid down in Article 107 of the Dutch Constitution that the general rules of administrative law had to be adopted by Act of Parliament. It is not without reason that this constitutional provision refers to 'general rules of administrative law'; it is expressly not the legislator's intention to come to a comprehensive, exhaustive administrative code. Before dealing with the codification of these general rules in the GALA, we will discuss the scope of administrative procedures in the Netherlands. Once this scope has been determined, it will be easier to understand the main features of the GALA.

\section{Scope of the Comparison: 'Administrative Procedure' in the Netherlands}

\section{Procedure}

Naturally, it is quite complex to define precisely what procedural law encompasses. In a general sense, 'procedure' does not mean the substantive standards governing the actions performed by administrative authorities. For example, procedure does not extend to the substantive standard that defines for what kinds of building projects an administrative authority may issue a permit. Rather, administrative procedure refers to the general rules governing the acts performed by the administrative authority, such as the rules about the decisionmaking process, including the preparation of the order. In addition, the rules and principles that determine when an order enters into force or when it is no longer valid are considered part of the law of administrative procedure in the Netherlands, as are the rules governing the possibilities of amending and revoking orders that have been made earlier. The Dutch law of administrative procedure also provides for rules for decision periods, including a provision for an authority's failure to make an administrative order timely. If the administrative authority fails to make an order within the relevant decision period, a citizen may serve a notice of default on it, after which it incurs a default penalty. ${ }^{7}$

In the Netherlands, the applicable rules of administrative procedure are determined to a great extent by the type of action taken by administrative authorities. As is shown by section 4, Dutch administrative law is concerned mainly with besluiten (usually translated into English as 'orders', sometimes as 'decisions'; for the sake of consistency, besluit is translated as 'order' in this text). Orders come in various forms, like regulations, plans, policy rules and individual decisions. The administrative rules applicable differ from type to type and mainly regulate individual decisions. In this context, it is also relevant whether an order is made at the request of a private party or on the initiative of the administrative authority itself. Participation rights and rules of evidence may vary, for example.

Dutch administrative law does not provide for special procedures such as inquiries or hearings, like those in the United Kingdom, but specific Dutch administrative authorities do have the power to institute an inquiry at companies, for example, for the purposes of supervision and enforcement. In addition, in various fields of administrative law public participation meetings are held, which enable interested parties to express their views on the draft of a 
proposed order. Cases of this kind frequently involve the application of the public preparatory procedure of Division 3.4 of the GALA, which will be addressed below.

Rules and principles concerning administrative transparency and access to data retained by public authorities are partly governed by procedural law. These concern the rules on the right of inspection of documents relating to the case in hand retained by the administrative authority and the requirement of transparency with respect to the allocation of scarce public-law permits. ${ }^{\mathbf{8}} \mathrm{A}$ doubtful case concerns the general regulation of access to data retained by the government. This right to accessibility of government information is enshrined in a separate statute, the Public Access Act (Wet openbaarheid van bestuur). Strictly speaking, this statute is not part of the system of administrative procedure and it has a somewhat more restricted scope because it does not apply to all administrative authorities. At the same time, this distinction is the subject of a broad debate and there are plans to incorporate the Public Access Act into the GALA.

By and large, procedural law concerning administrative authorities in the Netherlands has a broad scope of application. In fact, it encompasses all procedural rules that regulate acts and omissions of public authorities, even if Dutch administrative law regulates orders in particular, especially individual decisions. With such decisions, which are based on a public-law power, the government takes a unilateral measure that affects the legal position of the relevant party.

\section{Administrative law in relation to other branches of law}

There are quite a few subjects that might be considered part of administrative law in other legal systems, but that are regarded primarily as being of a constitutional nature in the Netherlands. These include the rules governing the election and appointment of specific officials and the organization of referenda. In general, the rules concerning the structure and operation of administrative authorities are part of constitutional law, such as the voting system used within administrative authorities of municipalities, provinces and regional water authorities. These constitutional rules often display greater diversity, because they do not fall under the GALA and the Constitution regulates hardly any practical matters. On the other hand, administrative courts may impose a sanction on non-compliance with rules of this kind if such non-compliance has resulted in an unlawful order.

In section 4, it will be made clear that the GALA relates mainly to orders, specifically individual decisions. In the Netherlands there is a clear difference between constitutionally regulated decision-making processes at central government level, which result in primary legislation, 'general administrative orders' (comparable to 'orders in council' in the UK and 'executive orders' in the US) and ministerial regulations on the one hand and administrative procedures on the other hand, which usually result in individual decisions (beschikkingen). The same difference exists at the decentralized level, when it comes to the preparation of generally binding regulations by municipal and provincial 
councils, inter alia. This more constitutional decision-making is hardly governed by the GALA at all. For example, under Article 1:1(2), under (a) of the GALA, the primary legislator is not regarded as an administrative authority and hence, it does not come within the scope of the GALA. Under Article 8:2 GALA, no appeal lies to the administrative court against rules. The Dutch legal system is not familiar with a concept like the notice-and-comment rulemaking procedure or with other modes of formal participation rights of individuals in rulemaking. This might be a consequence of the pluralistic political party system and the traditional 'polder model' in the Netherlands. This kind of system is based on consensus, which may be very hard to reach within coalitions and should not be too easily overturned. That said, interested parties may appeal against their individual implementing decision and then put forward that the decision is based on unlawful rules or they may appeal to a civil law court. However, such an appeal is hardly ever successful, as the courts generally pay great deference to choices made by rulemakers.

Even though there is a clear boundary between procedures resulting in rules and administrative procedures resulting in individual orders, it should be noted that administrative authorities may, in a substantial number of cases, choose to achieve policy objectives through generally binding regulations or through orders. For example, the chemical industry may be required to achieve an emission reduction through a system of permits to which conditions are attached (by means of individual orders), but administrative authorities may also choose to issue a generally binding rule forcing all companies involved to achieve an emission reduction. In some cases, an administrative authority on policy arguments will choose for the latter measure, for the purpose of preventing more accessible review by an administrative court. However that may be, this shows that the boundary between the two procedures is fuzzy in practice.

In addition, there are subjects that are associated with civil law rather than administrative law. The provisions concerning agreements, including the rules governing the formation and execution of contracts, are laid down in the Dutch Civil Code. This code does not contain separate provisions on contracts with the government. The civil court may, however, flesh out the open standards defined in the general rules by applying administrative standards, such as the general principles of sound administration. Like disputes concerning acts without an intended legal effect (deeds of fact or feitelijk handelen), disputes about such contracts are submitted to the civil court.

\section{Administrative and judicial procedures}

It is definitely possible to draw a boundary between administrative and judicial procedures. This boundary lies where an interested party files a notice of appeal with the administrative court against an order made by an administrative authority. By now9, there is a clear demarcation between administrative and judicial bodies in the Netherlands. Courts are designated as such in the Judiciary (Organization) Act (Wet op de Rechterlijke Organisatie), the Administrative Jurisdiction (Trade and Industry) Act (Wet bestuursrechtspraak bedrijfsorganisatie), the Council of State Act (Wet op de Raad van State) and the Social Security Appeals Act (Beroepswet), in conjunction with the General 
Administrative Law Act, and must satisfy strict requirements in terms of independency, inter alia. This does not apply to administrative authorities.

Even so, there is an important intermediate stage between the issue of an order and access to the court in the Netherlands. As a general rule interested parties are required to follow a preliminary administrative procedure (usually an objection procedure) before they can take their case against an order to court. ${ }^{\mathbf{1 0}}$ This procedure allows the individual to explain why he or she disagrees with the order, after which the administrative authority considers its order once again. Officially, this preliminary procedure has two objectives: extended decisionmaking and legal protection. In practice, the emphasis often lies on the latter element, which gives the objection procedure a quasi-judicial nature. ${ }^{\mathbf{1 1}}$ As a result, there could be a 'grey zone' between administration and adjudication after all. The Netherlands does not have specialist tribunals, such as those in the United Kingdom, but these objection procedures often involve committees composed partly of content experts. ${ }^{\mathbf{1 2}}$

The importance of administrative procedure law in judicial proceedings can hardly be overstretched.13 The administrative court reviews the lawfulness of orders made by an administrative authority ex tunc (without considering facts and circumstances which became relevant after the date of the order). In reviewing the appealed order, Dutch administrative courts attach great significance to the administrative authority's observance of the principles of due care and adequate reasoning. In its rulings the court emphasizes any mistakes the administrative authority may have made in the decision-making process. Should the administrative authority have conducted a more thorough examination, or should it have heard interested parties or sought additional advice? Due to this method of review, administrative procedure law is of paramount importance and it has exhibited a higher degree of development than judicial procedure law.

Besides, the great emphasis on administrative procedure is reinforced by the tendency of Dutch administrative courts to defer to the administrative authority's exercise of discretionary powers, which allows the courts to carry out the 'test of reasonableness' (i.e. judicial review limited to whether administrative powers have been exercised reasonably). A concept like 'the only correct legal relationship' is unknown to Dutch legal scholarship and vague standards in regulation may be construed to mean, explicitly or implicitly, that there is administrative discretion. Where the court carries out the test of reasonableness, it tends to concentrate its review of the order on the more procedural standards the administrative authority had to observe.

In addition, substantive review is hindered by the fact that the administrative court is often a generalist court. Many judges are subject to a rotation scheme, under which, for example, a judge who has worked in the administrative law sector for three years is transferred to the criminal-law sector. It is mainly the support staff, such as judicial clerks, who have the relevant substantive expertise with respect to specific administrative statutes.

In yet another respect, there is a certain degree of intermingling between administrative proceedings and court proceedings in the Netherlands. If the administrative court rules that an order is unlawful, it will annul the order and 
instruct the administrative authority to issue a new order. Until recently, as a general rule the procedure then came to an end and interested parties could initiate procedures all over again, against the new order. Over the last years courts have adapted their line of case law and now as general rule try to settle disputes definitively. To that end, the courts have recently been granted the power to render an interim decision, after ruling that an order is unlawful, requiring the administrative authority to issue a new order or to provide better reasons for its old order (during the process). ${ }^{\mathbf{1 4}}$ This is also known as the 'administrative loop' (bestuurlijke lus). This new tool enables courts to manage the decision-making process in the administrative stage to an increasing extent. The relevant case law also shows a trend, which will be put on a statutory footing in the future, where, after an order has been annulled, courts issue more and more specific directions to the administrative authority for the structure of the new order to be issued.

\section{The Codification of the GALA}

The preparation of the General Administrative Law Act took a long time. As early as 1982, the government set up an initial working party led by the then State Secretary of Justice, Michiel Scheltema, which was assigned the job of drafting general rules of administrative law. In addition to legislative staffers, administrative law academics invariably sat on this commission. The Scheltema Commission stated that the most important objective of the codification of the general rules of administrative law was the promotion of uniformity of administrative legislation. Further, administrative legislation had to be systematised and, where possible, simplified and significant administrative case law developments could be codified. Finally, the Commission considered the possibility of adopting general rules for administrative law subjects that, by their nature, are not suitable for specific statutes. In the end, the preliminary drafts drawn up by the Scheltema Commission evolved into the General Administrative Law Act (GALA).

The GALA is a piece of legislation that continues to evolve. It is a 'modular Act' as it is called, which means it is enacted in tranches. The first two major tranches of the Act entered into force on 1 January 1994. These tranches laid a solid foundation of an Act designed to provide a regulatory framework for administrative authorities that issue orders and to grant interested parties the right of appeal to the administrative court. Accordingly, the Act regulates both the administrative decision-making process and the legal protection against it. In 1998 a third tranche was enacted (mainly on supervision over administrative authorities) and 2009 saw the enactment of even a fourth tranche (mainly on rules of enforcement and, more specifically, on administrative fines). In addition, minor and major legislative proposals designed to supplement the GALA are instituted quite regularly, which means it is an ongoing legislative process.

\section{Nature and structure of the GALA}

Given the objective of making administrative law uniform, the legislator had to make some fundamental choices. In the explanatory memorandum to the first 
tranche, the legislator mentions some themes that may show a 'fundamental orientation'. In quite a detailed fashion, it deals with the general approach of the legal relationship between administrative authorities and citizens. It argues that this relationship has developed into a 'mutual relationship' between administration and individuals. The legislator advanced a larger responsibility for individuals, resulting in procedural duties such as the duty to state the grounds of appeal and to adduce evidence. Many scholars objected to this view, because of the unilateral lawmaking power of the administration and more than 15 years later, we have to conclude that, although the procedural obligations of individuals have increased significantly, the concept of a mutual relationship did not take root.

It was especially judicial procedure law that prompted the legislator to present fundamental considerations about the nature of administrative law and the duties of the court. An important development is that the legislator gave priority to legal protection over the principle of legality. This means that if any order conflicts with specific rules but the interested party has not objected to that, the order does not have to be annulled. In doing so, the legislator has opted to develop procedural law in the direction of a 'recours subjectif', which trend has indeed become stronger over time. In this context, the legislator attaches significance to judicial efficiency; procedural law should be both effective and efficient. In addition, there should be a low threshold for administrative proceedings. Individuals should be able to go to court at low costs, with few formalities and without an attorney-at-law. The court is active and may, if necessary, counterbalance the inequality between the individual and the administrative authority. This fundamental orientation has an impact on the law of administrative procedure as well. During the decision-making, too, an individual should be able to defend his or her position easily. Naturally, the administrative authority is required to observe the principle of legality, but it should also explicitly consider speed and judicial efficiency.

Apart from the foregoing, the General Administrative Law Act - and indeed, Dutch administrative law in general ? is not defined by dogmas to a great extent; the Act is of quite a practical nature. This may be illustrated by the example of the participation rights of individuals. ${ }^{\mathbf{1 5}}$ In preparing orders, administrative authorities are required to involve individuals in the decision-making process in advance only to a limited extent. ${ }^{\mathbf{1 6}}$ They solely have to hear interested parties and only to the extent their information is deemed important for establishing the correct facts for the purposes of the individual decision; notions of procedural justice are not a relevant factor at this stage. Only if the rejection of an application is based on information on facts that relate to the applicant individually and this information differs from the information he or she supplied, is the administrative authority required to give the applicant the opportunity to state his view. Similarly, interested parties who did not file any application have the right to be heard only if the decision prepared is based on information that relates to them. In addition, these hearing rights can be discarded if the decision concerns only financial obligations or whenever the need for expedition requires this exception. Not until interested parties appeal against an order (within the administration), do they have full rights to a hearing. ${ }^{17}$ 
Aside from these general considerations, it is mainly the following three key definitions in the GALA that denote the fundamental orientation of the Act: administrative authority, interested party and order. ${ }^{\mathbf{1 8}}$ Article 1:1 of the GALA contains a definition of an administrative authority; subsequently, the GALA provides for general rules governing acts performed by administrative authorities. Most rules in the GALA relate to specific acts, namely 'orders' (besluiten). Article 1:3 GALA includes a definition of an order made by an administrative authority: a written decision of an administrative authority constituting a public-law juridical act. This provision determines to a great extent the scope of the rules of the GALA and the scope of Dutch administrative law in general, as was already shown in section 3. An appeal to the administrative court lies only against orders of administrative authorities (Art. 8:1 GALA). Appeals may be filed only by 'interested parties', a concept defined in Article 1:2 GALA. Prior to the GALA, the right of appeal of interested parties was often restricted to individual decisions (beschikkingen). It was the legislator's intention that the GALA should broaden the scope of administrative law and that orders (including regulations and plans) should be the central concept of administrative law. The Act provided that after five years the exclusion of the right to appeal against rules would be abolished. After several years, however, the legislator feared a huge incentive for people to file appeals and maintained the exclusion in Article 8:2 GALA.

These key definitions have had a major harmonising effect, because they apply to the full range of administrative law. Whenever a special law empowers any administrative authority to issue an order, it is required, when exercising such powers, to comply with the GALA rules. If the administrative authority fails to do so, an interested party may, as a general rule, request the administrative court to annul the order.

After the key definitions in the first chapter, the second chapter of the GALA continues with general rules about dealings between citizens and administrative authorities. These rules apply to all dealings between individuals and administrative authorities and are of a very general nature. For example, Article 2:4 GALA includes a general provision prohibiting administrative authorities from performing their duties in a biased manner. There are some relatively new provisions about electronic communication between administrative authorities and interested parties. ${ }^{\mathbf{1 9}}$

Chapter 3 contains general provisions on orders, such as provisions concerning the preparation and notification of orders and the duty to state reasons for them. This chapter places important quality requirements on the decision-making practice. For example, orders must be prepared with due care (Art. 3:2 GALA); powers may not be used for a purpose other than that for which they were conferred by the legislator (Art. 3:3 GALA) and the interests concerned must be weighed in a proportionate manner (Art. 3:4 GALA). Division 3.4 includes special provisions governing extensive public preparatory procedures. This procedure must be followed if an order involves many interested parties, or if many interests must be balanced against each other, for example, in the case of infrastructure projects. In that case, a draft order is made available for inspection and interested parties have the right to be consulted. Not until this public participation process has finished is the final order made. From the perspective of administrative procedures, Division 3.5 GALA, with its heading 'Related Orders', is also of interest. It imposes an obligation of means on 
administrative authorities to inform individuals and businesses, applying for licences or grants for a specific activity, in the best possible manner about other orders for which an application must be filed, before they are permitted to perform the activity. Further, this division contains coordination rules for streamlining procedures for related orders.

Next, Chapter 4 GALA includes provisions on specific types of orders, such as individual decisions and, particularly, on orders granting subsidies and orders relating to money debts arising from administrative law. There are provisions, for example, allowing interested parties to express their views and to participate, on the time limit for orders and on what an interested party can do if the administrative authority fails to meet this time limit.

Chapter 5 of the GALA relates to the enforcement of regulation by administrative authorities. It provides for general rules for administrative sanctions that are important in practice, including the 'administrative enforcement order' (last onder bestuursdwang) (i.e. an administrative measure for the restoration of a legal situation) and the administrative fine.

Many of the rules in Chapters 2 to 5 contain 'open standards'. ${ }^{20}$ The administrative authority may, for instance, refuse to consider incomplete applications; it must act with due care, provide reasons for its orders and it must, in the case of an administrative enforcement order, state the time limit within which the violator can carry out the enforcement order. Often, the act does not prescribe in precise terms how the administrative authority should give substance to these general rules. As a result administrative authorities have a considerable scope of discretion to decide on the details of the general procedural rules. ${ }^{\mathbf{2 1}}$ This is why case law analysis is an important factor in Dutch administrative law studies, because it is only by means of this casuistry that the meaning of the general rules can be properly grasped. ${ }^{\mathbf{2 2}}$

Chapters 6, 7 and 8 contain rules for legal protection under administrative law. Bearing in mind the focus of the questionnaire, we will just say that it is mainly individual decisions that can be challenged on appeal before an administrative court, usually only after a preliminary procedure within the administrative system has been followed. In most cases, rulings of administrative courts are open to appeal to the Administrative Jurisdiction Division of the Council of State (the successor to the above-mentioned Judicial Division). ${ }^{\mathbf{2 3}}$ Chapter 9 of the GALA deals with complaint handling by administrative authorities and Chapter 10 contains provisions on conferral of powers and delegation of the power to make orders and the requirement of approval of orders by other administrative authorities (supervision of administrative authorities). The final provisions of the Act, which includes the duty to draw up evaluation reports, are laid down in Chapter 11.

As a result, the GALA has become a 'layered' act, structured from general towards ever more specific provisions. For example, where an administrative authority makes an order to pay an advance in anticipation of a sum of money to be paid later (Art. 4:95 GALA, included in Division 4.4 GALA), the rules of Chapter 2 concerning dealings between individuals and administrative authorities are applicable to this order, as are the provisions on orders laid down in Chapter 3. Further, the specific provisions relating to individual decisions of Division 4.1 of the GALA are applicable. Naturally, the same is true of the statutory provisions governing the special area of law within which the claim to 
an administrative sum of money is created, for example, under social security legislation.

\section{Relationship between the GALA and specific legislation ${ }^{24}$}

In addition to the GALA, there are a great many specific administrative laws. The relationship between general and special rules is defined primarily by the possibilities specified by the GALA itself for drafters of legislation in special branches of law to vary from and supplement the general rules. In this context, four kinds of general rules can be distinguished. First, the GALA contains mandatory provisions. These are rules that are applicable, without any exception, to administrative law as a whole, for example, the rule that administrative powers may not be used for a purpose other than for which they were conferred (Art. 3:3 GALA). Secondary legislators cannot make an exception to the foregoing. Apart from mandatory law, the GALA includes rules that are considered the 'best regulation' for normal cases, but that can be departed from in special cases, also by secondary legislators. This holds true, for example, of the provision that an application for an individual decision must be submitted in writing (Art. 4:1 GALA): sometimes it should also be possible to do so orally, because the standard rule includes the phrase 'unless otherwise provided by law'. In addition, there are situations where it is hard to define a generally applicable rule, but where it is desirable to create a 'residual provision' in case the drafters of special legislation fail to include a provision. An example can be found in Art. 4:13 GALA. The time limit for an individual decision depends on the type of decision applied for and that is why this time limit had better be laid down in a special law. However, in the absence of a special time limit, the general (and waivable) GALA provision applies, which states that the decision must be rendered within 'a reasonable period', which cannot exceed eight weeks in that case. Finally, the GALA contains provisions that may well be called 'optional'. The above-mentioned Division 3.4 concerning the extended preparatory procedure for orders is a case in point. This uniform preparatory public procedure is applicable if it is so provided by the special legislator or by the relevant administrative authority making the order.

Consequently, the GALA provides for an inherently flexible regulatory framework for Dutch administrative procedures, leaving the drafters of special laws and administrative authorities a wide scope of discretion in some respects. In addition, it should be borne in mind that the GALA does not have a special status as an Act of Parliament. This means that special laws of the same status (i.e. other Acts of Parliament) may permit departures from the GALA. Even so, the 'Drafting Instructions for Legislation' (Aanwijzingen voor de regelgeving) $\mathbf{2 5}$ provide that departures from GALA should be permitted only where these are necessary and that the reason for the departures must be stated in the explanatory memorandum to the special statute. Important specific statutes containing departures from the GALA include the Aliens Act 2000 (Vreemdelingenwet 200o) and the Crisis and Recovery Act from 2010 (Crisisen herstelwet), which was designed to accelerate the realization of major infrastructure projects in particular.

\section{Towards uniformity in administrative law}


All in all, the enactment of the first four tranches of the GALA and some smaller legislative proposals formed a legislative operation that cannot be easily surpassed, in terms of its scope and speed, in the Netherlands. The operation not only introduced a fundamental general Act with a broad scope of application but also triggered a huge operation to amend other legislation. The legislation needed to amend special laws, so as to bring them in line with the provisions of the GALA, comprises thousands of amendments spread across hundreds of statutes. The impact of this Act on Dutch administrative law has therefore been great; some have even called it a cultural revolution in the field of administrative law. Where previously those seeking general concepts and principles of administrative law had to explore a patchwork of special branches of law, special laws and case law of special administrative courts, the GALA, with its basic definitions and general rules, now provides some structure.

As a result, administrative law has become far more accessible; the academic debate can now be held on the basis of unequivocal concepts; case law in one specific branch of law may now be relevant to another branch of law; and the various highest administrative courts in the Netherlands have started to consul each other's case law. To this extent, the GALA has triggered a process leading towards greater uniformity.

\section{Main debates relating to administrative procedure and the GALA}

One cannot say that the codification of general administrative law in the GALA has been preceded by a very fierce debate, which is probably due to the broad composition of the Scheltema Commission, the general character of the code and its evolving nature. Nevertheless, the GALA project has been criticized in the Netherlands right from the beginning and to this very day. Initially, there was a great deal of resistance from various special branches of law and the line ministries. The general rules of GALA would leave insufficient room for carefully shaping the decision-making with due regard for the special characteristics of the branch of law concerned. ${ }^{\mathbf{2 6}}$ The question what subjects were suitable to be regulated in general rules was also discussed. For example, not everyone was convinced that rules on subsidy orders belonged in the GALA. The choice and prioritization of subjects addressed by the GALA were criticized anyway. In time, many experts regretted the absence of a comprehensive view on the legislative project of the GALA. Over the years, it seemed that the legislator particularly paid attention to subtopics, which were put on the political agenda more or less randomly. Even now, it is often pointed out that the present GALA fails to deal with obvious topics, such as provisions on the withdrawal of individual decisions as well as provisions on administrative contracts.

At this juncture, some main debates on administrative law are being held against the background of the GALA and a few proposed amendments. After a long period in which more and more safeguards were built in to administrative procedures for the benefit of individuals, driven by the needs of democratization and legal protection, there is currently a major emphasis on greater efficiency, speed and cost control. The idea that current administrative law provides too many safeguards for individuals is expressed primarily by politicians and representatives of administrative authorities. One of the solutions is to allow 
public participation or a day in court to fewer individuals or entities. Over the past few years, restrictions in this area have been imposed mainly on associations and foundations that defend general interests.

In addition, administrative law is said to be far too complex, also due to the rapid succession of legislative amendments (especially in the field of environmental and planning law). It is argued that this complexity restricts the government's ability to act effectively for the public interest. Further, the idea exists that many built-in safeguards in fact do not contribute to high-quality decision-making, but to delays. For this reason, the legislative process is now showing a clear focus on developing faster procedures. Finally, as is hardly surprising given the financial crisis, there is a clear focus on cost management. Very briefly, one might say that where from the 1970s, there was a focus on the safeguard function of administrative law, there is now a greater focus on its instrumental function. For example, the possibilities for the court to disregard specific defects in administrative orders have been broadened in recent years. This means that if an order does not meet specific formal standards, it need not always be annulled. Naturally, this has consequences for the manner in which administrative authorities structure their decision-making processes, because they do not have to be afraid that their orders will be annulled by the court due to technicalities.

In this context, the proposed and controversial introduction of a 'relativity requirement' or 'protective norm criterion' as it is called (better known as a schutznorm) in general administrative law should be mentioned as well. Application of the relativity requirement will mean, for example, that undertakings can invoke only standards that are actually designed to protect their interests. To date, this requirement does not apply as yet, except for the special regime of the Crisis and Recovery Act. Currently, interested parties may enforce compliance with all standards applicable to the government before an administrative court. The introduction of the relativity requirement will change that and make it easier for administrative authorities to ignore specific substantive standards.

These developments could be perceived as being an example of the trend towards reducing the judicial elements in conflicts and relationships ('dejuridification' or 'dejudiciarisation'). But this is too simple a conclusion, because the application of the relativity requirement will trigger a technical legal debate. In addition, it is said that the proposed measures referred to above help to create administrative law of a kind that effectively gives means of challenging orders only to very alert and well- educated individuals: those who attend public hearings, go to the town hall to inspect draft orders, raise objections to these in a timely manner, lodge well-substantiated notices of appeal and submit counteradvice in order to refute the advice rendered by administrative authorities. Although litigation without compulsory legal representation is a formal principle of Dutch administrative law, it is increasingly difficult to defend a case without engaging a specialized lawyer. In fact, these developments only raise the amount of litigation between individuals/undertakings and the government. Such actions by administrative authorities and the administrative courts - whether encouraged by the legislator or otherwise - are therefore fiercely criticized by those focusing on the position of individuals in administrative law. They point out that administrative authorities usually issue 
orders that are of poor quality and that they adopt too formalistic an attitude, with counterproductive effects as far as effective administration is concerned. On this issue, there seems to be an arms race. Where individuals/undertakings defend themselves against administrative authorities by engaging increasingly specialized lawyers, the legislator/government responds by taking measures like broadening the possibilities for the court to disregard specific violations and by introducing financial thresholds for the performance of specific administrative acts (such as administrative charges) and increasing court registry fees to gain access to an administrative court. Many public law scholars consider this a worrying development.

Like the increasing complexity of administrative rules, the expertise of administrative authorities is another important issue. As a result of the everwidening scope of administrative law because of the ever-growing role of the government, administrative authorities are required to have technical expertise in many areas. Examples include complicated environmental issues, the assessment of the remaining earning capacity of a disabled person and - in the context of the ever-increasing economization of administrative law - the question whether a merger between two undertakings will result in a conglomerate with significant market power within the meaning of competition law. Where, one the one hand, administrative authorities are expected to gain more and more technical expertise, the government is no longer able, on the other hand, to engage experts to a sufficient degree as a result of budget cuts. Consequently, the quality of administrative orders is under pressure, which can only partly be compensated for by the engagement of consultants.

It remains difficult for generally educated public servants and judges to properly appreciate specialized information. For example, many questions arise where the administrative authority is confronted with two expert reports that contradict each other. As a result of this development, too, particularly the procedural rules relating to consultancy ${ }^{\mathbf{2 7}}$ are being developed, where it is an important question who bears the burden of proof and should engage the expensive experts.

In line with the criticism of the complexity of administrative law, there is criticism that the GALA has resulted in the 'juridification' of the relationship between administrative authorities and individuals. Given its general nature, the GALA contains mostly procedural rules and as a result, decision-making shows a strong focus on procedure. It is argued that administrative authorities are clinging too much to rules and are making little use of substantive decisionmaking, including more policy-related balancing of interests. In particular, the preliminary administrative objection procedure has become increasingly formal, with administrative authorities often seeking advice from complaints committees with external (often legally trained) members. These committees review administrative orders in an almost judicial manner.

It is also said that the jurisdiction provisions in the GALA reinforce the juridification trend. Individuals cannot submit their entire 'relationship' with the administration to the court, but only the issues that arise from orders that have been issued. Consequently, a multitude of fragmented procedures may arise. This strong orientation of the GALA on the 'order' concept is increasingly being criticized, but it is very doubtful whether this fundamental orientation will soon 
be discarded in a country where the judicial review of administrative action developed with difficulty. If jurisdiction under the GALA extended to acts without any intended legal effect and civil-law juridical acts, these acts would probably be governed by the rules of the GALA to a greater extent.

There is certainly positive news in this area, too. In recent years, the Ministry of the Interior and Kingdom Relations has been calling for a more informal approach (for which it also received an international award). ${ }^{\mathbf{2 8}}$ Administrative authorities should focus less on the legal side of objections and more on the importance and nature of the objection lodged by individuals. A fair and courteous treatment attracts a great deal of governmental attention. For example, under the new approach, administrative authorities must invite objectors for a personal interview within a few days. This results not only in more satisfied individuals and less litigation, but also saves the government a considerable amount of money. By now, the judiciary is also experimenting with a more informal hearing, emphasizing the interests underlying the conflict and the need for procedural fairness.

Finally, an important debate in the Netherlands concerns the question whether the pursuit of generally applicable administrative law has gone too far. Undeniably, the GALA has contributed to the positive development of administrative law in the Netherlands, but now the question arises whether there should be more room for tailor-made solutions. The procedural rules would have to be adjusted a little, depending on the branch of law concerned and the specific legal relationship at issue, inter alia, taking account of the interests concerned and the professionalism of the parties. For example, it has been suggested that administrative authorities should prepare an order on an asylum application quite differently? with more care ? than an application for planning permission for a dormer. The flexibility offered by the GALA itself is not always perceived as sufficient.

On the other hand, where the legislature is experimenting with variations from the GALA, these often attract a great deal of criticism as well. A recent phenomenon is that legal concepts which differ from the GALA rules are put to the test in special laws, also for the purpose of ascertaining whether they could eventually be incorporated into the GALA. In particular, the above-mentioned Crisis and Recovery Act provides an example. What is particularly problematic is that this statute constitutes a temporary infringement of the GALA (the Act expires on 1 January 2014), but that the current right-wing government is so content with this system of reduced legal protection, that it intends to convert it into a permanent law even before it has been evaluated.

This government plan is in line with the coalition agreement signed in 2010, which stipulates that the government will come up with proposals for the simplification and modernization of the GALA. To this end, proposals are made to adjust judicial proceedings, with the main objective of enabling the court to reach a final settlement of a dispute more frequently. Furthermore, under this banner the informal approach of the preliminary administrative procedure is emphasized and there is a slight departure from the order-oriented model (with respect to damages for an unlawful act). The GALA will be further amended and supplemented in the near future. 


\section{International/European Influence}

Finally, we will reflect on the impact of international law on Dutch administrative law. This impact is great, as the relevant provisions of the Dutch Constitution (Articles 93 and 94) are based on the notion of direct effect of international law within the Dutch legal system. Individuals can invoke selfexecuting treaty provisions in court, and in case of any conflict, these will prevail over national law. The direct effect and supremacy of EU law follows, as is generally known, from the supranational nature of this treaty law itself and so this also applies to the Netherlands.

From the beginning, the GALA legislator has been aware of the international context. Besides the needs of the users and politicians, the legislator had to operate within a framework where the Constitution, the principles of law, EU law and international conventions like the ICCPR and the ECHR play a role. The Benthem ruling issued by the Strasbourg Court ? in which this court ruled that one of the pillars of the Dutch legal protection system, the appeal to the Crown, is incompatible with the independence requirements of Article $6 \mathrm{ECHR}^{\mathbf{2 9}}$ ? has certainly reinforced this awareness. This ruling from 1985 was a real eye-opener for administrators and administrative lawyers in the Netherlands alike. It became clear that the ECHR and in particular Article 6 of the Convention, which had attracted hardly any attention when the ECHR was approved in the 1950s, could certainly be important to administrative law and, hence, to the GALA.

In order to keep this report within reasonable limits, we will focus our attention on the impact of EU law and the ECHR, as the main sources of internationalization in this area of law, on the general Dutch rules concerning administrative procedures.

\section{EU influence}

The significance of EU law for Dutch administrative law can hardly be overestimated. In an increasing number of branches of substantive law, the European Union directly or indirectly prescribes rules for administrative acts. For example, agricultural law, the law on fisheries and transportation and customs law have long been dominated by the European legislator. To the extent that these areas still leave room for national implementing legislation, such legislation is based on European concepts and principles. The situation is different for general administrative law. Although the principles of Dutch administrative law are influenced by European developments, one cannot say that its foundations have been affected by these. The EU legal system of implementation, execution and enforcement of Community law by means of national law, within the limits of equivalence and effectiveness, usually ${ }^{\mathbf{3 0}}$ allows the Netherlands to cling to concepts and principles formed in the course of history, except for some strategic adjustments. ${ }^{\mathbf{3 1}}$ Even so, due to the GALA, the special areas of law are studied in a more integral fashion by means of the basic concepts of the GALA. As a result, European law aspects and the special features of these specific branches of law more easily penetrate the debate on the general part of administrative law.

Given the above mentioned developments, it is understandable that the GALA 
legislator has increasingly focused on European law aspects during the legislative project. It can be established that the first clear signs of influence are especially related to specific high-profile affairs. For example, as a consequence of the 'ESF affair', which resulted in the Netherlands having to repay the European Commission hundreds of millions of euros in European subsidies, the focus of Dutch subsidy law shifted to European law aspects. In this context, the legislative proposal for the recovery of state aid has been brought before Parliament, inter alia. This legislative proposal concerns a standard scheme that is to be added to the GALA enabling administrative authorities to comply with their Community obligations under state aid law. After this Act will be entered into force, administrative authorities will generally be entitled to take withdrawal and recovery decisions, when the case law of national or European courts shows that unlawful state aid has been provided. Administrative authorities will also be allowed longer decision times for cases in which they must verify whether the aid they intend to provide is compatible with the EU Treaty. A second European development in the GALA, with a more positive origin, is the result of the European Services Directive. In order to implement the Directive, the Dutch legislator has drafted the Services Act but, interestingly enough, also it made ??changes to the GALA, while this was not strictly necessary. The lex silencio positivo rule required under the directive is included in a general provision in the GALA, so this instrument could be used in 'nonEuropean' cases as well ${ }^{\mathbf{2}}$, a clear example of European influence on general administrative law in the Netherlands.

In addition to these examples of influence by European law resulting in legislation, it should be noted that this influence is clearly shown in the relevant case law. These concern, in addition to aspects of administrative procedure, particularly interpretations of general principles of sound administration. These are obviously important to the law concerning administrative procedures; they also determine the standards of the decision- making process. In recent years, it has become clear that the Dutch legal certainty principle and the principle of legitimate expectations, for example, cannot be fully applied in European cases. If, for example, recovery decisions must be taken by national authorities, Dutch administrative courts are required, where disputes arise about these, to apply a stricter interpretation by virtue of European case law, which gives individuals less protection. An interesting question is whether such stricter interpretation, in the context of the pursuit of legal unity and equality, is also applicable (or should be applicable) to purely domestic recovery disputes. There is a lively debate on that issue. For the time being it seems that in domestic cases, Dutch administrative courts adhere to the Dutch doctrine.

An example of a new general principle of sound administration is the principle of transparency, which was unknown to Dutch administrative law, but which the administrative courts increasingly apply, inspired by European law. This principle of law resulting from the right to equal treatment is ever more read into the principle of careful preparation of orders in the Netherlands. Especially in case of allocation of limited public authorizations and grants, this principle is of great importance for the actions of the administrative authorities. Although the precise meaning of the transparency principle and its importance for Dutch administrative law has not yet crystallized, it can be expected that the principle will eventually lead to amendments to the GALA. 


\section{ECHR}

The ECHR has left a clear mark on Dutch administrative law, not least because of the aforementioned infamous Benthem case. The legislature was well aware that the structure of administrative legal protection has to meet international human rights standards, where it paid special attention to Article 6 ECHR. In preparing the third tranche of the GALA, the law concerning administrative procedures in relation to the ECHR is discussed as well; especially the question which administrative penalties qualify as 'criminal charge' attracts a great deal of attention.

By now, the GALA has existed more than 15 years while it is 60 years since the ECHR came into effect and it can be established that the GALA is regularly assessed against the ECHR. Whether or not on the initiative of litigants or legal scholars, the legislator, the courts and the administration regularly examine whether the ECHR requires amendments to the GALA itself or changes to its application in, inter alia, case law. The need for this has increased over the years as the GALA has expanded considerably and applies to more and more areas, while the Strasbourg Court has developed the ECHR into a finely woven set of rules through its dynamic interpretation.

All in all, the ECHR has become a constant factor in the legislative process of the GALA, which, on the one hand, seeks to achieve a fair and careful procedure and, on the other hand, focuses, especially in recent years, on the timely completion of procedures and the final settlement of disputes. In the national case law, the GALA ? particularly Article 6 - is regularly assessed against the ECHR. It is clear that the GALA generally passes the ECHR test very well and the ECHR is at best used for supplementing and supporting the GALA rules. The Strasbourg case law shows no examples of any rulings against the Netherlands directly resulting from the application of the GALA. In this sense, it appears that the efforts of the legislator and the Dutch courts to shape and apply GALA in accordance with ECHR bear fruit. The Strasbourg case law does show examples of adverse rulings that may be associated ? in a more general sense ? with more structural flaws in our system of administrative law, which deserve attention. This particularly applies to the failure to settle disputes definitively within a reasonable period; the use of too formalistic barriers in the legal protection system, and, according to Strasbourg, too restrained and limited review of administrative orders in specific cases (especially in immigration law) where highly fundamental interests are at stake.

\section{Conclusion}

The GALA has been a milestone for the regulation of administrative procedures. With the introduction of this Act on general rules of administrative law, more uniformity and systematization has been achieved. As long as specific statutes specify no exceptions, the same rules apply to all administrative orders: the same obligation to hold a hearing, the same decision period, the same obligation to inform a party of his right to remain silent. Through this standardization, the GALA has brought administrative law as a field of study to a higher level. Administrative authorities, courts and legal scholars use the same vocabulary to explain the rules and principles. In addition, as a result of the general concepts, the impact of EU law and the ECHR on national administrative law as a whole 
has become visible.

Even so, the codification also has drawbacks, which relate to the general nature of the Act. General rules that apply to the full range of administrative law are primarily procedural in nature. Because of the introduction of the GALA, the procedural side of decision-making has received much attention ? perhaps too much. This has resulted in a trend known as 'juridification', which may be at the expense of the substantive review of orders. Critical comments on this do not fall on deaf ears and have prompted the Ministry of the Interior and Kingdom Relations to try to exert influence in an informal manner on the decision-making culture of administrative authorities. This does not result in amendments to the GALA, as the legislator steadily continues to supplement the Act with legal constructions designed to accelerate decision-making processes and to reduce the individual procedural rights of interested parties.

Questionnaire for the IACL conference on Codification, subgroup Codification of Administrative Procedure (drafted by professor Jean-Bernard Auby)

I. Scope of the comparison: what do we mean by «administrative procedure»?

a. «Procedure»?

We will probably agree on including:

The way administrative decisions appear: requests, how they are treated, delays, audi alteram partem, due process ...

The status of administrative acts: form, modification, abrogation ...

Functioning of administrative bodies: quorums ...

Special procedures like inquiries, hearings ...

Does your domestic law consider also as belonging to "administrative procedure":

Processes through which rule making decisions are made: notice and comment ...

Direct interventions of citizens in administrative matters: election of officers, administrative referenda ...

Procedures concerning the making and the implementation of public contracts

Rules and principles concerning the validity of administrative acts

Rules and principles concerning administrative transparency, access to public data? 
b. «Administrative»

i. Does your national law draw a distinction between governmental processes (which would not be subject to the rules concerning "administrative" procedure) and administrative ones?

ii. Where is, in your system, located the boundary between administrative and judicial procedure?

Is there a clear-cut divide between administrative and judicial bodies, or is there a grey zone of "tribunals", situated in between courts and "pure" administrative entities?

In relation to this, what is the scope of the law concerning administrative procedure?

II. Main features of the law on administrative procedure in your country (apart from whether it is codified or not)

a. Historical development, origin of its basic principles (legislation, case-law ...)

b. Fundamental orientations

c. Importance of the procedural dimension in your administrative law

d. What are the main debates related to administrative procedural law: Simplification? Democratization? Others?

e. How far is your national law on administrative procedure influenced by international (European) rules and standards?

III. Is your national law on administrative procedure codified?

IV. If it is codified:

a. When was it codified?

What were the reasons accounting for that?

Was there a strong debate about: Making a code? The content of the code?

What were the sources of administrative procedure law previously?

b. How is the code structured? Which are the main concepts that determine its architecture?

Is it based upon a concept of administrative act? If so, how is this 
concept delimited? Have regulatory acts made by administrative authorities the nature of administrative acts, or are they of a different nature?

Are contractual procedures within the code's perimeter?

c. What margin of freedom does it leave to administrative authorities in the arrangement of their procedures?

d. What room does it allow to direct participation of the citizens?

e. Was the codification process the occasion for a special effort in the sense of conceptualization and theorization of administrative procedure law?

f. What was the ambit of the codification?

i. Does there still exist special pieces of legislation about administrative procedure, which complement the code, or deviate from it?

g. As to the effects of the codification

i. What room did it leave to jurisprudential creation?

ii. Has it been considered as satisfactory (in terms of administrative efficiency, in terms of simplification, in terms of democratization ...)?

V. If your national law on administrative procedure is not codified

a. Is there a (doctrinal or political) debate on codifying?

b. What are the sources of procedural administrative law (Constitution, statutory legislation, governmental regulation, soft law, case-law)

c. What room for jurisprudential creativity?

d. To what extent are administrative authorities free to adapt general rules to their own procedural needs?

e. What room for direct participation of the citizens in administrative processes?

f. How does your administrative law cope with demands (if such demands exist) for procedural simplification?

\section{Noten}

1 The GALA (translation in English) can be found at www.rijksoverheid.nl. 
2 This article has been written for the International Academy of Comparative Law's conference on Codification, held in Taipei, May 2012. The article is based on the questionnaire included in appendix 1.

3 Standard textbooks on Dutch administrative law and the law of administrative procedure include the following: H.D. van Wijk, W. Konijnenbelt \& R.M. van Male, Hoofdstukken van bestuursrecht, The Hague: Elsevier Juridisch 2011; M. Schreuder-Vlasblom, Rechtsbescherming en bestuurlijke voorprocedure, Deventer: Kluwer 2011; R.J.N. Schlo?ssels \& S.E. Zijlstra, Bestuursrecht in de sociale rechtsstaat, Deventer: Kluwer 2010; L.J.A Damen, Bestuursrecht: Dl. 2, Rechtsbescherming tegen de overheid, bestuursprocesrecht, The Hague: Boom Legal Publishers 2009; T. Barkhuysen, W. den Ouden, J.E.M. Polak \& G.A.C.M. van Ballegooij, Bestuursrecht in het Awb-tijdperk, Deventer: Kluwer 2008; L.J.A Damen, Bestuursrecht: Dl. 1, Systeem, bevoegdheid, bevoegdheidsuitoefening, handhaving, The Hague: Boom Legal Publishers 2005. As for English-language and French-language literature, reference is made to the following works: P.C. Adriaanse, T. Barkhuysen, W. den Ouden \& Y.E. Schuurmans, 'Faciliter la mise en oeuvre de droit communautaire: l'exemple de droit administratif néerlandais.', Revue Française d'Administration Publique, 2009, 129, pp. 131151; J.M.J. Chorus, P.H.M. Gerver, E.H. Hondius, Introduction to Dutch law, Alphen aan den rijn: Kluwer Law International 2006; J.G Brouwer \& A.E. Schilder, A Survey of Dutch Administrative Law, Nijmegen: Ars Aequi Libri 1998. Caselaw research can be conducted on www.rechtspraak.nl (public database of the judiciary).

4 Questionnaire II.a.

5 Questionnaire I.b. Nowadays, there is a clear-cut divide between administrative and judicial bodies, but this has not always been the case. The Dutch supreme administrative law court (the Administrative Jurisdiction Division of the Council of State) has developed out of an administrative body and for a long time, appeal lay mainly to this administrative body ('the Crown'). Article 6 of the ECHR prompted the replacement of this kind of legal protection by a final appeal to a 'real' court.

6 Questionnaire IV.a.

7 Article 4:17-4:20 GALA.

8 See $\S 6$.

9 See footnote 4 .

10 Article 7:1 GALA.

$\mathbf{1 1}$ This is generally considered to be a negative development and there are various initiatives designed to make the procedure more informal again; see $\S 5$.

12 Article 7:13 GALA. 
13 Questionnaire II.c.

14 Article 8:51a GALA..

15 Questionnaire IV.d. See Articles 4:7 - 4:12 GALA.

$\mathbf{1 6}$ This is different for the extensive public preparatory procedures of Division 3.4 GALA.

17 Article 7:2 GALA.

18 Questionnaire IV.b.

19 Articles 2:13-2:17 GALA.

20 Questionnaire IV.c.

$\mathbf{2 1}$ The administrative authority may also make policy rules thereon.

22 Questionnaire IV.g.i.

23 The Dutch appeal system is quite fragmented. In some cases, appeal lies to other appellate courts, such as the Central Appeals Tribunal, the Trade and Industry Appeals Tribunal or the Tax Courts.

24 Questionnaire IV.f.

25 A circular used at government ministries.

26 So far, especially the Ministry of Finance has been notorious for its adoption of special rules for procedures on tax law.

27 Articles 3:5-3:9 GALA.

28 The United Nations Public Service Award 2011 for the project 'Informal proactive Approach Model', see

http://unpan1.un.org/intradoc/groups/public/documents/undpadm/unpano45540.pdf.

29 ECHR decision dated 23 October 1985, Benthem v. the Netherlands, AB 1986, 1, with a note by Hirsch Ballin, NJ 1986, 102, with a note by Alkema, NJCM-Bulletin 1985, p. 669 et seq., with a note by Zwart; AB Klassiek, sixth edition, Deventer: Kluwer 2009, no. 10, pp. 139-150, with a note by Barkhuysen.

30 The legality requirement is an exception, as far as this requirement is concerned, administrative courts offer fierce resistance where it is affected as a result of the European principle of effective implementation.

31 Standard literature on the Europeanisation of Dutch administrative law includes J.H. Jans, S. Prechal, R.J.G.M. Widdershoven, Inleiding tot het 
Europees bestuursrecht, Nijmegen: AAeL 2011.

32 Articles 4:20a-4:20f GALA.

(c) Boom Juridische uitgevers 
